\title{
Development and Testing of a SREX Flowsheet for the Partitioning of Strontium and Lead from Simulated ICPP Sodium-Bearing Waste
}

J. D. Law

D. J. Wood
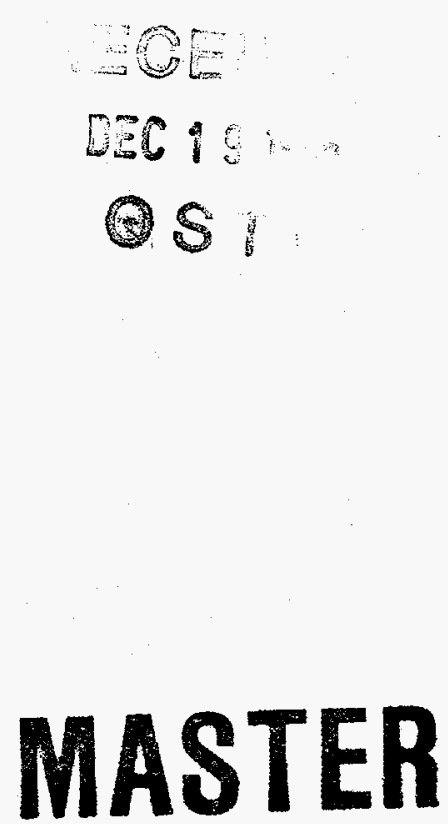

Engineering Laboratory 
INEL 96/0437

\title{
Development and Testing of a SREX Flowsheet for the Partitioning of Strontium and Lead from Simulated ICPP Sodium-Bearing Waste
}

\author{
J. D. Law \\ D. J. Wood
}

Published November 1996

\begin{abstract}
Idaho National Engineering Laboratory
Waste Management Technologies

Lockheed Martin Idaho Technologies Company

Idaho Falls, Idaho 83415
\end{abstract}

Prepared for the

U.S. Department of Energy

Assistant Secretary for

Environmental Management

Under DOE Idaho Operations Office

Contract DE-AC07-94ID13223 


\begin{abstract}
Laboratory experimentation has indicated that the SREX process is effective for partitioning ${ }^{90} \mathrm{Sr}$ from acidic radioactive waste solutions located at the Idaho Chemical Processing Plant. Previous countercurrent flowsheet testing of the SREX process with simulated waste resulted in $99.98 \%$ removal of $\mathrm{Sr}$. With this previous test, however, $\mathrm{Pb}$ was extracted by the SREX solvent and was not backextracted in the dilute nitric acid strip section. The $\mathrm{Pb}$ concentration increased in the recycled solvent and in the aqueous phase of the strip section, resulting in the formation of a $\mathrm{Pb}$ precipitate.

Subsequently, studies were initiated to identify alternative stripping agents which will selectively strip $\mathrm{Sr}$ and $\mathrm{Pb}$ from the SREX solvent. Based on the results of these studies, a countercurrent flowsheet was developed and tested in the $5.5-\mathrm{cm}$ Centrifugal Contactor Mockup using simulated waste. The flowsheet tested consisted of an extraction section ( $0.15 M 4^{\prime}, 4^{\prime}(5)$-di-(tert-butyldicyclohexo)-18-crown-6 and 1.2 $M$ TBP in Isopar- $\mathrm{L}^{\circledR}$ ), a $0.05 \mathrm{M}$ nitric acid strip section for the removal of $\mathrm{Sr}$ from the SREX solvent, a $0.1 \mathrm{M}$ ammonium citrate strip section for the removal of $\mathrm{Pb}$ from the SREX solvent, and a $2.0 \mathrm{M}$ nitric acid equilibration section. The behavior of $\mathrm{Sr}, \mathrm{Pb}, \mathrm{Al}, \mathrm{Ca}, \mathrm{Hg}, \mathrm{Na}, \mathrm{Zr}$, and $\mathrm{H}^{+}$was evaluated. The described flowsheet successfully extracted and selectively stripped $\mathrm{Sr}$ and $\mathrm{Pb}$ from the SBW simulant. Removal efficiencies of $97.9 \%$ and $99.91 \%$ were obtained for $\mathrm{Sr}$ and $\mathrm{Pb}$, respectively. Essentially all of the extracted $\mathrm{Sr}(99.998 \%)$ and $1.9 \%$ of extracted $\mathrm{Pb}$ exited with the $0.05 \mathrm{M}$ nitric acid strip product; whereas, $0.002 \%$ of the extracted $\mathrm{Sr}$ and $97.9 \%$ of the extracted $\mathrm{Pb}$ exited with the $0.1 \mathrm{M}$ ammonium citrate strip product. Also, $95 \%$ of the $\mathrm{Hg}$ and $63 \%$ of the $\mathrm{Zr}$ were extracted by the SREX solvent.
\end{abstract}





\section{ACKNOWLEDGEMENTS}

The authors would like to express their appreciation to T. G. Garn, R. D.Tillotson, P. A. Tullock, and E. L. Wade for their assistance with laboratory testing, operation of the centrifugal contactors, chemical makeup, and sample preparations.

Many thanks to J. S. Laug and S. D. Nielsen of the Spectrochemical Analysis Group for the efficient, expedient sample analysis. Without the work and dedication of these people, this test could not have proceeded. 



\section{CONTENTS}

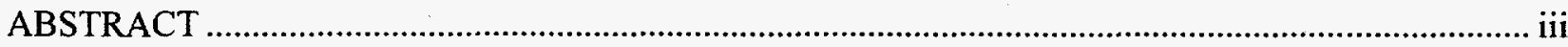

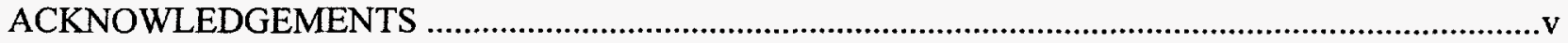

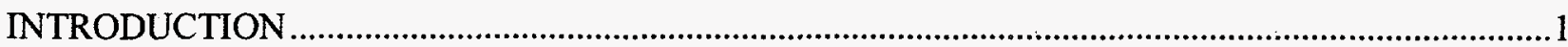

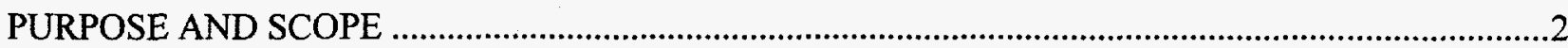

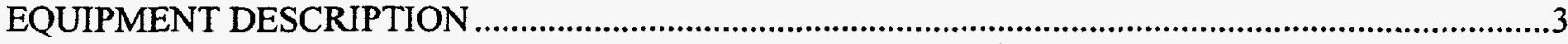

METHODOLOGY/EXPERIMENTAL PROCEDURE

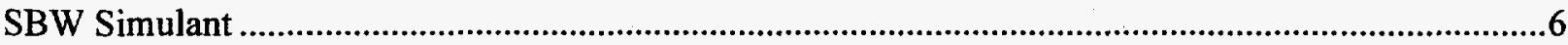

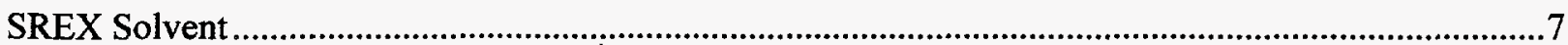

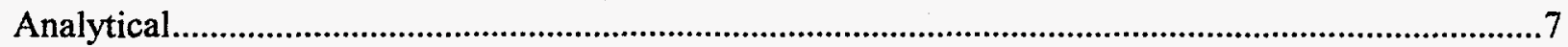

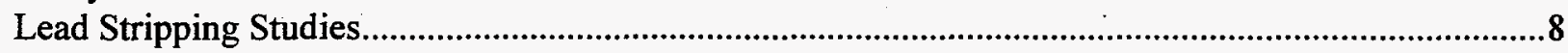

SREX Flowsheet Testing in the Centrifugal Contactors ....................................................................

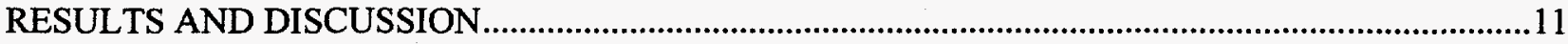

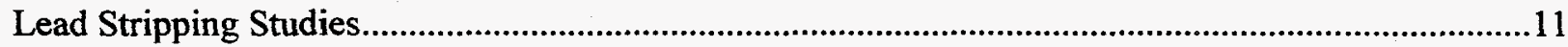

Nitric Acid Dependence for the Extraction of Strontium and Lead ............................................11

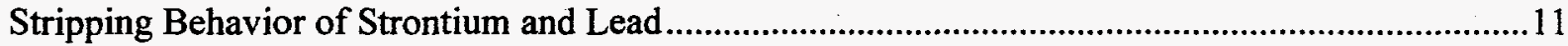

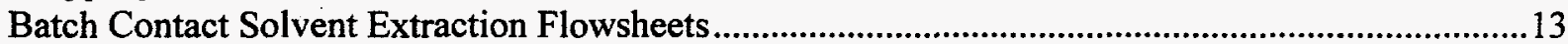

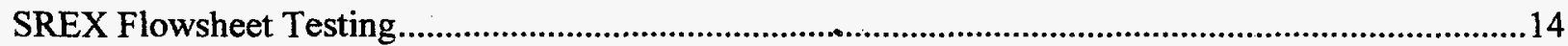

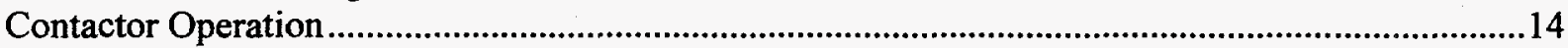

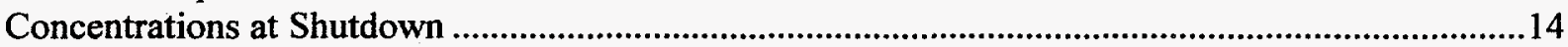

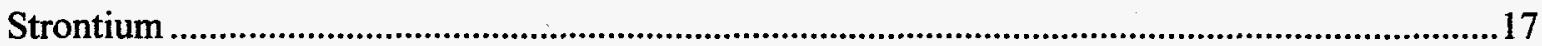

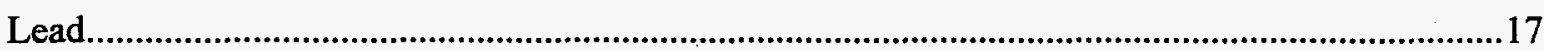

Aluminum, Calcium, Sodium, Mercury, and Zirconium .......................................................17

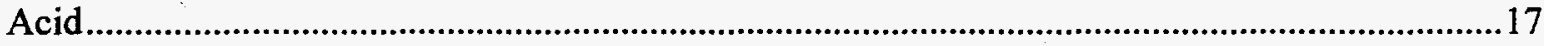

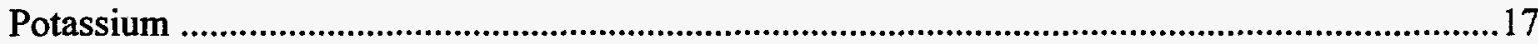

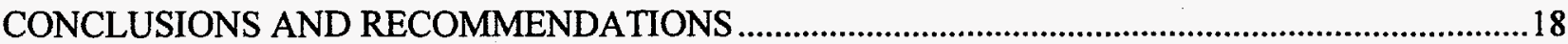

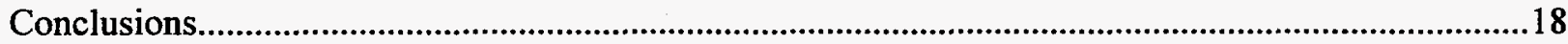

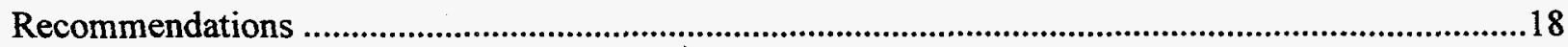

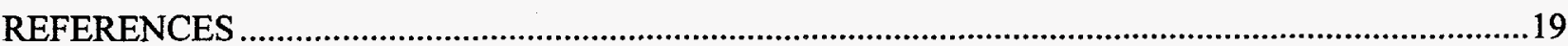

APPENDIX A: EXPERIMENTAL DATA 


\section{TABLES}

Table 1. Centrifugal contactor description. .3

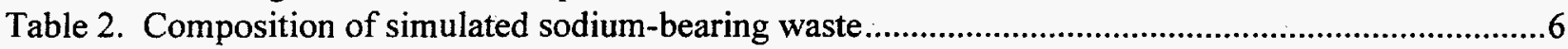

Table 3. Amount of Sr present in the aqueous phase as percent of total. ................................................12

Table 4. Amount of $\mathrm{Pb}$ present in aqueous phase as percent of total ................................................12

Table 5. Distribution coefficients for batch contact flowsheet .........................................................13

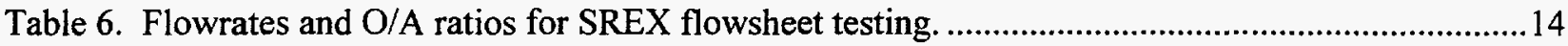

Table 7. Percentage of component in each of the effluent streams for SREX flowsheet testing ..............16

Table 8. $\mathrm{Sr}$ and $\mathrm{Pb}$ distribution coefficients for SREX flowsheet testing ..............................................16

\section{FIGURES}

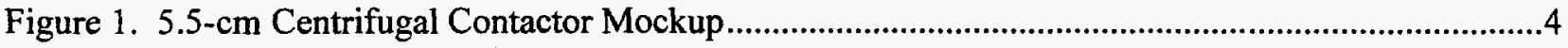

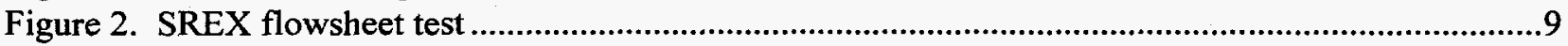

Figure 3. Dependence of distribution coefficients on initial nitric acid concentration for $0.001 \mathrm{MPb}(+)$ and $0.001 M \mathrm{Sr}(\Delta)$. Organic phase: $0.15 \mathrm{MDtBuCH} 16 \mathrm{C} 6$ and $1.2 \mathrm{M}$-tributyl phosphate in Isopar LB.

Figure 4. SREX flowsheet test steady state concentrations 


\section{Development and Testing of a SREX Flowsheet for the Partitioning of Strontium and Lead from Simulated ICPP Sodium-Bearing Waste}

\section{INTRODUCTION}

The Idaho Chemical Processing Plant (ICPP), located at the Idaho National Engineering Laboratory (INEL), formerly reprocessed spent nuclear fuel to recover fissionable uranium. The radioactive raffinates from the solvent extraction uranium recovery processes were converted to granular solids (calcine) in a high temperature fluidized bed. During the course of reprocessing, a secondary waste stream, liquid sodium-bearing waste (SBW), was also generated primarily from equipment decontamination between campaigns and solvent wash activities. This SBW cannot be directly calcined due to the high sodium content and has historically been blended with reprocessing raffinates or nonradioactive aluminum nitrate prior to calcination. Fuel reprocessing activities are no longer being performed at the ICPP, thereby eliminating the option of waste blending to deplete the SBW inventory. Currently, approximately 1.5 million gallons of liquid SBW are temporarily stored at the ICPP in large underground stainless-steel tanks.

The United States Environmental Protection Agency and the Idaho Department of Health and Welfare filed a Notice of Noncompliance in 1992 contending some of the underground waste storage tanks do not meet secondary containment requirements as set forth in Title 40, Part 265.13 of the Code of Federal Regulations. As part of a 1995 agreement between the State of Idaho, the Department of Energy, and the Department of Navy, the SBW must be removed from the tanks by 2012.

Several technologies are currently being evaluated for the treatment and final disposition of SBW inventories. These technologies include blending with nonradioactive chemicals, effectively diluting the sodium, followed by calcination of the liquid; and radionuclide partitioning followed by immobilization of the resulting high-activity and low-activity waste streams. A peer review for the INEL separations group identified the most promising radionuclide separation technologies for evaluation. ${ }^{1}$ The Transuranic Extraction process, developed by Horwitz and Schulz ${ }^{2}$, was identified as a primary candidate for separation of the actinides from ICPP SBW. The Strontium Extraction (SREX) process, developed by Horwitz ${ }^{3}$, was identified as a primary candidate for separation of ${ }^{90} \mathrm{Sr}$ from ICPP SBW.

A major emphasis at the ICPP has been directed toward evaluating ${ }^{90} \mathrm{Sr}$ separation from SBW using the SREX process. The active extractant used in the SREX process solvent is $4^{\prime}, 4^{\prime}\left(5^{\prime}\right)$-di-(tertbutyldicyclohexo)-18-crown-6 (DtBuCH18C6). Tributylphosphate (TBP) is added to the solvent as a phase modifier to prevent third phase formation and a paraffinic hydrocarbon is used as a diluent. The process has been effectively demonstrated to remove Sr from acidic SBW simulants and actual SBW solution to below the $0.04 \mathrm{Ci} / \mathrm{m}^{3} \mathrm{NRC}$ Class A low-level waste requirements. ${ }^{4,5}$ Previous testing of the SREX process with simulated SBW in $5.5-\mathrm{cm}$ centrifugal contactors resulted in $99.98 \%$ removal of $\mathrm{Sr}^{5}$ However, $\mathrm{Pb}$ was extracted into the SREX solvent and the strip section was ineffective in backextracting the $\mathrm{Pb}$. Lead built up in the SREX solvent and in the aqueous phase of the strip section, resulting in the formation of a precipitate in the strip section. Alternative stripping agents were subsequently investigated for stripping $\mathrm{Pb}$ from the SREX solvent. This report summarizes the results of laboratory experiments to identify alternative stripping agents as well as further SREX flowsheet testing for the extraction and selective stripping of $\mathrm{Sr}$ and $\mathrm{Pb}$ from simulated $\mathrm{SBW}$ using centrifugal contactors. 


\section{PURPOSE AND SCOPE}

The purpose of this study was to develop and demonstrate a SREX flowsheet which.will effectively extract and strip ${ }^{90} \mathrm{Sr}$ and $\mathrm{Pb}$ from ICPP SBW under continuous, countercurrent conditions using simulated SBW. Once the applicability of this process to SBW has been established, a comparison of the flowsheet to other technologies currently under development (e.g., cobalt dicarbollide solvent extraction) will be possible.

Laboratory batch contacts were performed using the SREX solvent and simulated SBW in order to evaluate an alternative stripping agent which will back-extract $\mathrm{Pb}$ from the SREX solvent without the formation of a precipitate. Ammonium citrate and nitric acid solutions were evaluated as potential stripping agents. Distribution coefficients for $\mathrm{Pb}$ and $\mathrm{Sr}$ were evaluated for each of the stripping agents. The formation of precipitates was also evaluated. As a result of these experiments, a potential SREX flowsheet was developed for the treatment of ICPP SBW. This flowsheet includes provisions for selectively stripping ${ }^{90} \mathrm{Sr}$ and $\mathrm{Pb}$ from the SREX solvent.

Sixteen stages of $5.5-\mathrm{cm}$ diameter centrifugal contactors were procured from Oak Ridge National Laboratory and setup as part of the Centrifugal Contactor Mockup. The modified SREX flowsheet was tested using this mockup. The location of the mockup precludes the use of radioactive solutions. Therefore, all flowsheet testing was performed using non-radioactive SBW simulant. The behavior of Sr and the non-radioactive components was evaluated for the potential flowsheet. Specifically, the ability to effectively strip $\mathrm{Pb}$ from the SREX solvent was evaluated. Potential problems such as solids precipitation, which were not apparent with batch contacting experiments, but could arise because of the solvent loading effects due to the countercurrent solution flow in the centrifugal contactors, were also evaluated. Previous flowsheet testing has already demonstrated the ability of the SREX flowsheet to reduce the ${ }^{90} \mathrm{Sr}$ activity to below the NRC Class A LLW limit of $0.04 \mathrm{Ci} / \mathrm{m}^{3}$ with one cycle of SREX $\left(>99.9 \%{ }^{90} \mathrm{Sr}\right.$ removal). ${ }^{5}$ The countercurrent SREX flowsheets developed with non-radioactive SBW simulant will be used for future countercurrent flowsheet development and testing with actual SBW. 


\section{DISCLAIMER}

This report was prepared as an account of work sponsored by an agency of the United States Government. Neither the United States Government nor any agency thereof, nor any of their employees, makes any warranty, express or implied, or assumes any legal liability or responsibility for the accuracy, completeness, or usefulness of any information, apparatus, product, or process disclosed, or represents that its use would not infringe privately owned rights. Reference herein to any specific commercial product, process, or service by trade name, trademark, manufacturer, or otherwise does not necessarily constitute or imply its endorsement, recommendation, or favoring by the United States Government or any agency thereof. The views and opinions of authors expressed herein do not necessarily state or reflect those of the United States Government or any agency thereof. 


\section{DISCLAIMER}

Portions of this document may be illegible in electronic image products. Images are produced from the best available original document. 


\section{EQUIPMENT DESCRIPTION}

All testing was performed in the Centrifugal Contactor Mockup located in building CPP-637. The Centrifugal Contactor Mockup, as shown in Figure 1, consists of sixteen stages of 5.5-cm diameter centrifugal contactors, feed and receiving vessels, feed pumps, flowmeters, filters, AC and DC motor drives, and a sample system.

Four stages of centrifugal contactors (assembled as a single unit or four-pack) were procured from Oak Ridge National Laboratory (ORNL) in 1986. Twelve additional stages were procured from ORNL in 1993. A description of the centrifugal contactors is provided in Table 1. All sixteen stages of contactors are basically identical with the exception of the type of motor.

Solution is fed to the contactors using Masterflex ${ }^{\circledR}$ pumps. Surge lines, consisting of an 18-inch section of 1-inch stainless steel tubing, were placed on the outlet of the pumps to dampen the surging flow. Rotameters were calibrated and used to monitor solution flowrates. Flowrates are adjusted by changing the pump speed using a ten-turn potentiometer.

Aqueous and organic feed solutions are filtered with two in-line sintered metal filters in series (20 micron and 5 micron). The filters are installed in glass tubing so that the buildup of any solids can be observed. In addition, pressure gauges were installed to monitor the pressure drop across the filters resulting from solids accumulation on the filters.

Clear flexible Teflon tubing is used for inlet and outlet connections to the centrifugal contactors. This allows solution flow to be observed and solution characteristics to be noted, i.e., color changes of the organic solution between contactor banks.

Table 1. Centrifugal contactor description.

\begin{tabular}{lll}
\hline & Original Four-Pack & Additional Twelve Stages \\
\hline Size & 5.5 -cm rotor diameter & 5.5 -cm rotor diameter \\
Motor & DC & $1 / 3 \mathrm{HP}$ AC \\
Controller & $\begin{array}{l}\text { Individual DC motor controllers } \\
\text { for each motor. 0-5,000 RPM } \\
\text { control. }\end{array}$ & $\begin{array}{l}\text { AC variable speed motor drive. } \\
0-3,500 \text { RPM control. }\end{array}$ \\
Material of Construction & 304L stainless steel & $\begin{array}{l}\text { 304L stainless steel } \\
\text { Sample Ports }\end{array}$ \\
& $\begin{array}{l}\text { Aqueous and organic exiting each } \\
\text { stage. Bottom access only. }\end{array}$ & $\begin{array}{l}\text { Aqueous and organic exiting } \\
\text { each stage. Top and bottom } \\
\text { access. }\end{array}$ \\
Aqueous Feed Stages & Stage 4 only & $\begin{array}{l}\text { Stages 2, 3, and 4 of each four- } \\
\text { pack }\end{array}$ \\
\hline
\end{tabular}




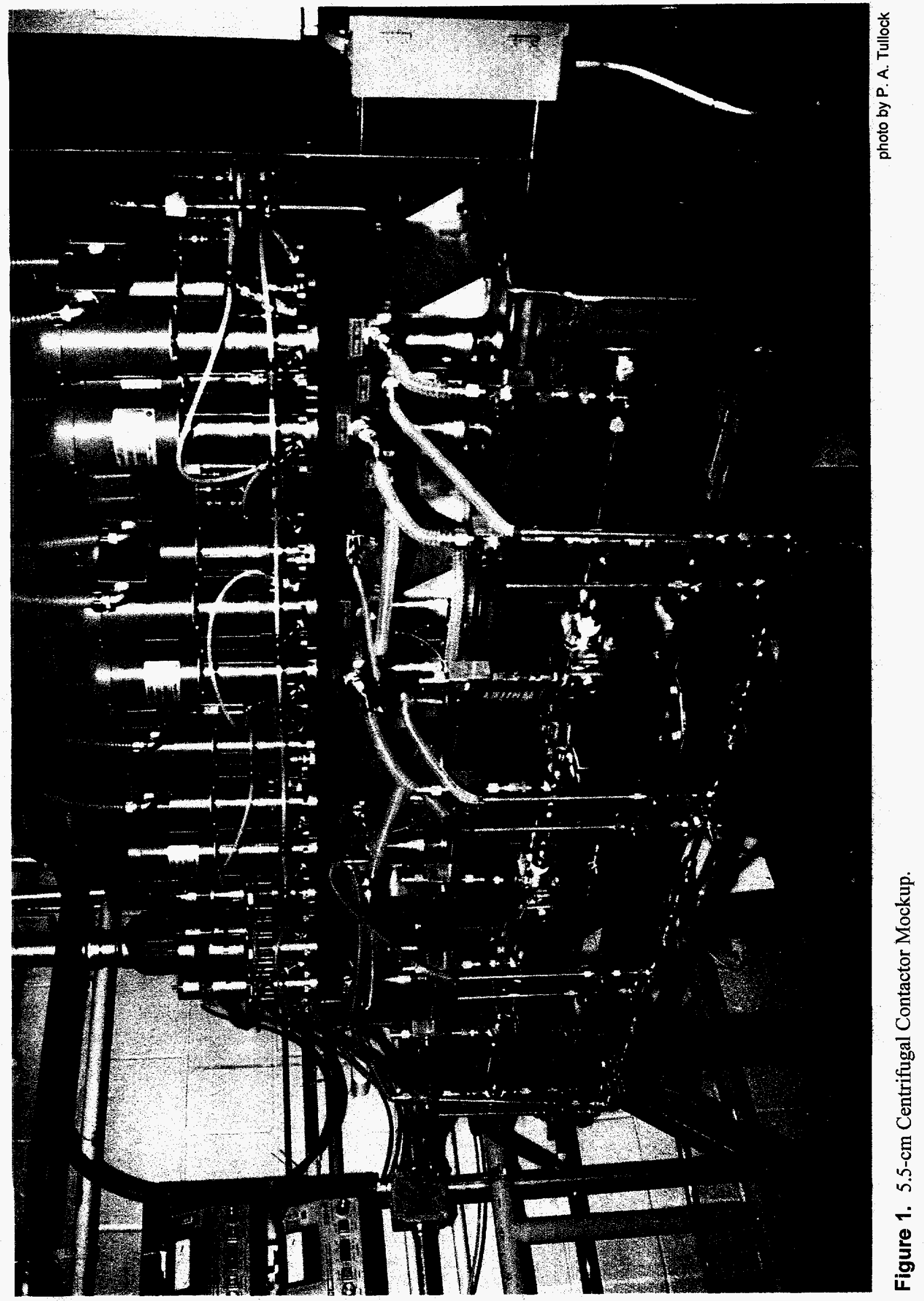


The aqueous raffinate, strip product, wash effluent, and solvent recycle streams were sampled by routing the solution draining to a receiving vessel into a sample bottle during the actual flowsheet test. Individual stage samples were taken by draining the contactor stages after shutdown.

An air purge system is connected to the contactor bearing housings. Purge air is required in order to protect the motor body, shaft, and bearings from corrosive process fumes. Air to the bearing housings passes through four rotameters, one for each contactor four-pack. The air flowrate through the rotameters can be adjusted from 0 to $5 \mathrm{scfh}$. Air from each rotameter is split to feed each of the four bearing housings. Orifices were placed in the lines to each bearing housing to keep the air flowrate into each housing approximately equivalent. The offgas from the bearing purge system combines with the offgas from the feed and product tanks and vents out of the building. 


\section{METHODOLOGY/EXPERIMENTAL PROCEDURE}

\section{SBW Simulant}

For the purposes of this study, the behavior of non-radioactive components in simulated SBW was evaluated. Using the analytical results obtained from characterization of SBW waste solution, a nonradioactive simulant was prepared to represent the average chemical composition of the major nonradioactive matrix components in the SBW tanks. Stable $\mathrm{Sr}$ was added to simulate radioactive $\mathrm{Sr}$. The stable Sr was added to the SBW simulant in higher concentrations than the actual waste contains in order to increase the accuracy of the analytical results for Sr. The chemical composition of the SBW simulant is shown in Table 2.

Prior to testing with SBW simulant in the Centrifugal Contactor Mockup, the feed solution was filtered with a 10 micron sintered metal filter to prevent plugging of the filters on the aqueous feed line during operation. Filtering the SBW simulant was required due to the formation of a sodium nitrate precipitate during the makeup of the simulant. This precipitate, which is a gel-like substance, settles to the bottom of the 55 gallon drum in which the SBW simulant is made. Solution is typically pumped out near the top of the liquid to prevent the plugging of the filter and minimize the chance that any solids will remain in the filtered SBW simulant feed. For the testing in the Centrifugal Contactor Mockup, the solution level in the drum was low, resulting in considerable plugging of the filter while pumping. It is expected that some of the precipitate passed through the filter and/or additional precipitate formed in the SBW simulant after being filtered. The specific components evaluated in this study include those species potentially extracted by the SREX solvent: acid, strontium, lead, sodium, aluminum, calcium, zirconium, and mercury.

Table 2. Composition of simulated sodium-bearing waste (SBW).

\begin{tabular}{cccc}
\hline Component & $M$ & Component & $M$ \\
\hline Acid $\left(\mathrm{H}^{+}\right)$ & 1.26 & $\mathrm{~K}$ & $1.38 \mathrm{E}-01$ \\
$\mathrm{Al}$ & $5.56 \mathrm{E}-01$ & $\mathrm{Mn}$ & $1.42 \mathrm{E}-02$ \\
$\mathrm{~B}$ & $1.40 \mathrm{E}-02$ & $\mathrm{Mo}$ & $1.49 \mathrm{E}-03$ \\
$\mathrm{Cd}$ & $2.05 \mathrm{E}-06$ & $\mathrm{Na}$ & 1.32 \\
$\mathrm{Ca}$ & $9.83 \mathrm{E}-02$ & $\mathrm{NO}_{3}$ & 4.46 \\
$\mathrm{Ce}$ & $3.63 \mathrm{E}-04$ & $\mathrm{Ni}$ & $1.63 \mathrm{E}-03$ \\
$\mathrm{Cl}$ & $3.52 \mathrm{E}-02$ & $\mathrm{~Pb}$ & $9.27 \mathrm{E}-04$ \\
$\mathrm{Cs}$ & $7.52 \mathrm{E}-05$ & $\mathrm{PO}$ & $<9.18 \mathrm{E}-03$ \\
$\mathrm{Cr}$ & $5.63 \mathrm{E}-03$ & $\mathrm{Sr}$ & $6.80 \mathrm{E}-03$ \\
$\mathrm{~F}$ & $9.66 \mathrm{E}-02$ & $\mathrm{SO}$ & $3.86 \mathrm{E}-02$ \\
$\mathrm{Fe}$ & $2.40 \mathrm{E}-02$ & $\mathrm{Zr}$ & $8.76 \mathrm{E}-03$ \\
$\mathrm{Hg}$ & $1.93 \mathrm{E}-03$ & & \\
\hline
\end{tabular}




\section{SREX Solvent}

The SREX solvent composition used in all SREX flowsheet studies reported herein was $0.15 M$ 4',4'(5')-di-(tert-butyldicyclohexo)-18-crown-6 and 1.2 MTBP in Isopar $\mathrm{L}^{2}$ and was prepared by the ICPP Quality Control Laboratory. The extractant was obtained from Eichrom Industries, Darien, Il. The performance of this extractant is extremely sensitive to the purity of the product. The extractant used in these tests was reported to yield a $\mathrm{D}_{\mathrm{Sr}}$ value of 3.8 according to Eichrom quality assurance procedures. The SREX process was originally developed using 1-octanol as the diluent. This selection was made because the flash point and flammability of this diluent were determined to present minimal risk in a process operation. However, octanol is known to form degradation products when placed in contact with nitric acid. The degradation products present unknown potential safety problems in the operation of the SREX process. In addition, it has been determined that the residual presence of 1 -octanol in the aqueous phase decreases the performance of CMPO in actinide removal in the TRUEX process during sequential waste treatment processes. An alternative diluent, therefore, has been studied to replace 1-octanol. The alternative solvent is composed of an isoparaffinic hydrocarbon diluent (Isopar $L^{\circledR}$ from Exxon Corp.) and 1.2 $\mathrm{M}$ TBP as a phase modifier. This solvent is compatible with the TRUEX solvent currently being studied at the ICPP.

The purity and composition of the SREX solvent were established prior to performing laboratory studies and prior to use in the centrifugal contactors. $\mathrm{D}_{\mathrm{S}_{\mathrm{r}}}$ was determined using the SREX solvent and 3.0 $M$ nitric acid solution in order to evaluate solvent purity and composition. This method of determining the strontium distribution coefficient was established as a quality control procedure for testing the initial SREX solvent and the SREX solvent product from each flowsheet test. If the results were within the acceptable range $\left(D_{\mathrm{Sr}}>2.5\right)$, the solvent was considered suitable for extraction studies.

Due to limited availability and the high cost associated with the DtBuCH18C6, only six liters of SREX solvent was prepared for testing in the Centrifugal Contactor Mockup. This limited quantity of solvent made it necessary to recycle the solvent during each flowsheet test in the centrifugal contactors. The SREX solvent was fed to the contactors out of a carboy and the solvent product leaving the strip section drained back into the feed carboy.

\section{Analytical}

All sample analyses were performed by the ICPP Analytical Section. $\mathrm{Sr}, \mathrm{Pb}, \mathrm{Na}$, and $\mathrm{K}$ analyses of the aqueous samples were performed using Inductively Coupled Plasma Atomic Absorption Spectroscopy (ICP-AES). Hg analyses were performed using Cold Vapor Atomic Absorption Spectrophotometry.

Experimental results obtained from batch contacts with SBW simulant indicate 1-hydroxyethane1,1-diphosphonic acid (HEDPA) is effective at quantitatively back-extracting all metals, except mercury, from the SREX solvent. ${ }^{5}$ Consequently, the organic samples from the flowsheet test were contacted with $0.25 \mathrm{M}$ HEDPA in $0.05 \mathrm{M}$ nitric acid. To insure quantitative metal recovery in a single contact, an $\mathrm{O} / \mathrm{A}$ ratio of 0.4 was used. The HEDPA was assumed to strip all of the $\mathrm{Sr}, \mathrm{Pb}, \mathrm{Na}, \mathrm{Ca}$, and $\mathrm{Zr}$, but not the $\mathrm{Hg}$, out of the SREX solvent. The aqueous phase from the HEDPA strip was separated from the solvent and submitted for $\mathrm{Sr}, \mathrm{Pb}, \mathrm{Na}, \mathrm{Ca}$, and $\mathrm{Zr}$ analysis. The solvent was then contacted with $0.05 \mathrm{M}$ ethylene diamine tetraacetic acid (EDTA) at an O/A of 0.4 to strip the $\mathrm{Hg}$ out of the solvent. This procedure provided an indirect measure of organic phase compositions and allowed the use of material balances to validate experimental results. For the batch contacts, the organic phase concentration was determined indirectly by chemical balance. However, selected data points in each of these experiments were reproduced subsequently with radiometric methods. 
For batch contact experiments with radioactive tracers, the analysis of both the organic and aqueous phases was performed by gamma spectrometry when ${ }^{85} \mathrm{Sr}$ was employed as the tracer. When ${ }^{210} \mathrm{~Pb}$ was employed, each phase was analyzed by liquid scintillation. Corrections for the grow-in of the daughter isotopes were performed for each phase in the liquid scintillation measurements. The measured activities in each phase were utilized to determine distribution coefficients for the measured species.

\section{Lead Stripping Studies}

Dilute nitric acid and ammonium citrate solutions were evaluated as potential $\mathrm{Pb}$ and $\mathrm{Sr}$ stripping reagents. The evaluation of the stripping reagents was performed by contacting a volume of the SREX solvent once with an equal volume of $3 \mathrm{M}$ nitric acid which contained $0.005 \mathrm{M}$ each of $\mathrm{Pb}\left(\mathrm{NO}_{3}\right)_{2}$ and $\mathrm{Sr}\left(\mathrm{NO}_{3}\right)_{2}$. Aliquots of this organic solution were then placed in separate containers for stripping experiments. The stripping procedure was performed by contacting the organic solution three times in succession with equal volumes of the appropriate stripping solution. The aqueous phases from each contact were sampled after centrifugation for analytical measurement.

Each of the experiments in this study was performed at room temperature $\left(27 \pm 2{ }^{\circ} \mathrm{C}\right)$ with equal volumes of the appropriate aqueous solution and organic extractant. It should be noted that the experiments described in this paper did not employ a preconditioning of the organic phase prior to extraction. The equilibrium concentration of acid in the aqueous phase, therefore, is likely to differ from the initial conditions due to the extraction of nitric acid and water by the organic phase. The organic and aqueous solutions were placed in glass centrifuge tubes and placed on a vortex-motion mixer for 1 minute unless otherwise stated. Following mixing, the samples were immediately placed in a centrifuge for one minute at $5,000 \mathrm{rpm}$. After centrifugation, the phases in each sample were separated for analysis with small volume Pasteur pipets.

Radioactive $\mathrm{Sr}$ and $\mathrm{Pb}$ tracers were employed for direct measurement of metal concentrations in aqueous and organic phases. The tracers which were employed in the batch extraction experiments were dispensed with a small volume motorized pipet (Rainin Instrument Co., Inc.) directly into individual aqueous solutions in test tubes. The tracer solutions were of sufficient activity to allow a small volume of tracer to be added which did not significantly increase the total volume of the aqueous samples.

\section{SREX Flowsheet Testing in the Centrifugal Contactors}

Based on the results of the $\mathrm{Pb}$ stripping studies and previous SREX flowsheet development studies performed in the 5.5-cm Centrifugal Contactor Mockup, a SREX flowsheet was recommended for further testing in the mockup. This flowsheet consists of four stages of extraction at an O/A of 1.0, four stages of $0.05 \mathrm{M}$ nitric acid strip at an O/A of 0.5 , four stages of $0.1 \mathrm{M}$ ammonium citrate strip at an O/A of 1.0, and four stages of $2.0 \mathrm{M}$ nitric acid rinse at an $\mathrm{O} / \mathrm{A}$ of 2.0. The resulting flowsheet used for the SREX flowsheet testing is shown in Figure 2. Due to the limited number of contactor stages available (16 stages), only four stages of extraction were tested instead of the desired eight. Results of previous flowsheet testing has already demonstrated that $99.97 \% \mathrm{Sr}$ removal will be obtained with this flowsheet. 


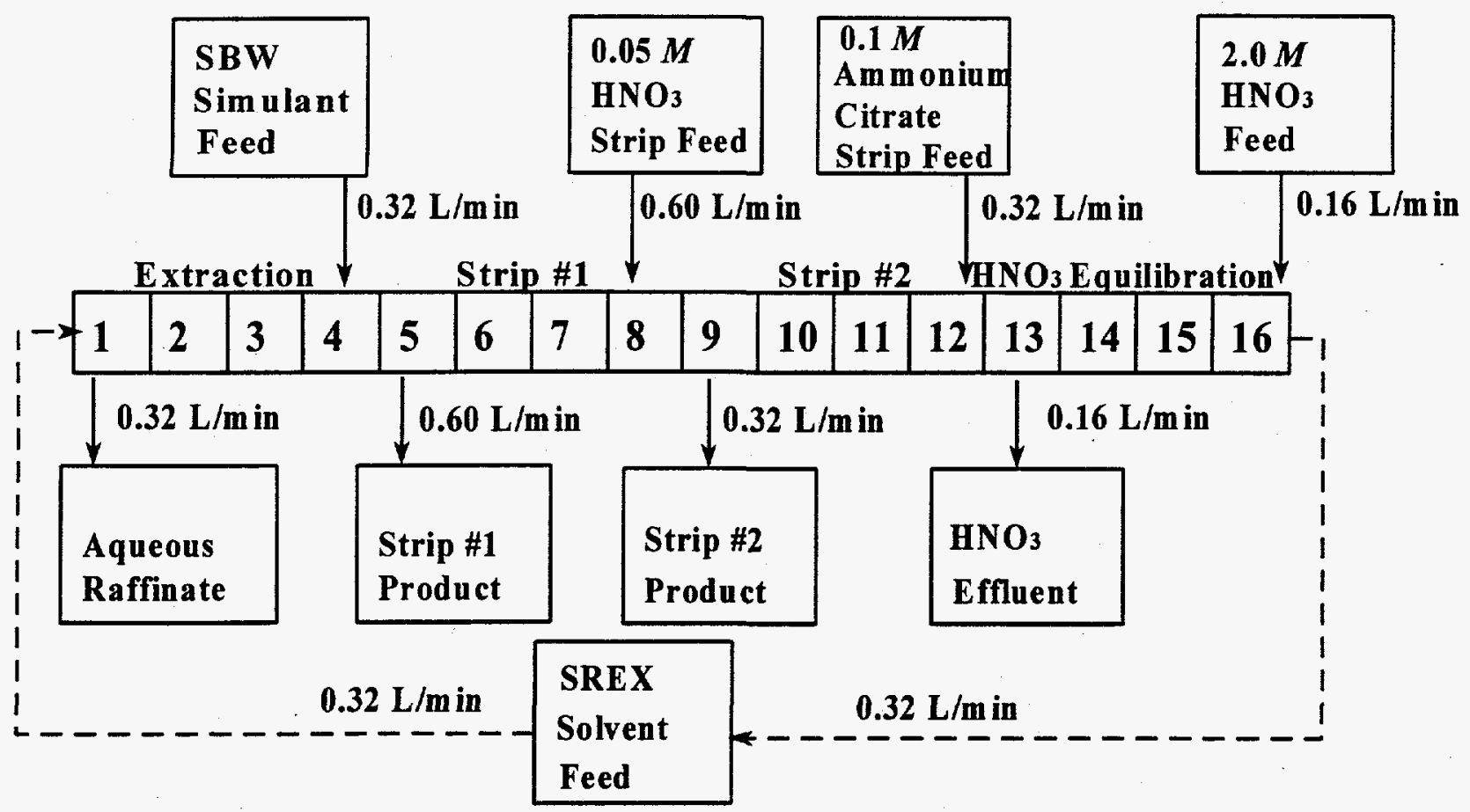

Figure 2. SREX flowsheet test.

The goals of the SREX flowsheet testing were to:

(1) Demonstrate the overall operability of the $5.5-\mathrm{cm}$ centrifugal contactors with the SREX flowsheet.

(2) Determine the concentrations and distribution coefficients of $\mathrm{Sr}, \mathrm{Pb}$, and $\mathrm{H}^{+}$for each stage at steady-state conditions.

(3) Evaluate the effectiveness of the SREX flowsheet in stripping Pb from the SREX solvent.

(4) Determine if any precipitate or third phase formation problems exist with this flowsheet.

SREX flowsheet testing was performed as follows. The centrifugal contactor motors were started at 3,000 rpm. All aqueous solution flows, except for the SBW simulant, were established. 2.0 M nitric acid was used as an initial SBW feed. When aqueous solution was observed exiting each of the sections, solvent flow was initiated. SBW simulant feed was started when solvent was observed exiting the extraction section. Forty-five minutes after the start of the aqueous feeds, the raffinate, strip products, acidification effluent, and solvent effluent streams were sampled. Based on the results of previous SREX flowsheet testing, the flowsheet was expected to have reached steady-state within 30 minutes after the start of SBW feed. Level readings on each of the feed tanks were also noted in order to determine actual solution flowrates based on tank depletion rates. The centrifugal contactors were then shutdown by simultaneously stopping the feed pumps and contactor motors. Each stage remains approximately at steady-state operating conditions with this type of shutdown. This allowed aqueous and organic samples to be taken from each stage and, therefore, distribution coefficients to be determined for each of the 16 stages. 
The following procedure was used to obtain aqueous and organic samples from each stage; 1) 20 mLs of aqueous were drained out of the contactor stage to flush the drain line, 2) $20 \mathrm{mLs}$ of aqueous sample were drained into a sample bottle for analysis, 3) the remaining aqueous and a portion of the organic were drained from the contactor stage, 4) $15 \mathrm{mLs}$ of organic were drained into a clean sample bottle, and 5) $10 \mathrm{mLs}$ of organic were pipetted off of the top and transferred to a sample bottle for analysis. 


\section{RESULTS AND DISCUSSION}

\section{Lead Stripping Studies}

\section{Nitric Acid Dependence for the Extraction of Strontium and Lead}

The extraction of $\mathrm{Sr}$ and $\mathrm{Pb}$ from nitric acid solutions by the SREX solvent has been studied in batch solvent extraction experiments. The measured distribution coefficients for $\mathrm{Sr}$ and $\mathrm{Pb}$ are dependent upon the initial concentration of nitric acid in the aqueous phase as shown in Figure 3 . The extraction curves show that the extraction of $\mathrm{Pb}$ from nitric acid solutions is more efficient than the extraction of Sr. In addition, the slopes of the plotted regression lines are dissimilar. The figure indicates that at low concentrations of nitric acid, the difference between the measured distribution coefficients for $\mathrm{Pb}$ and $\mathrm{Sr}$ is larger than the measured difference at higher acid concentrations. The extraction plots for $\mathrm{Pb}$ and $\mathrm{Sr}$ suggest that at higher acid concentrations, highly efficient removal of $\mathrm{Pb}$ and $\mathrm{Sr}$ is possible.

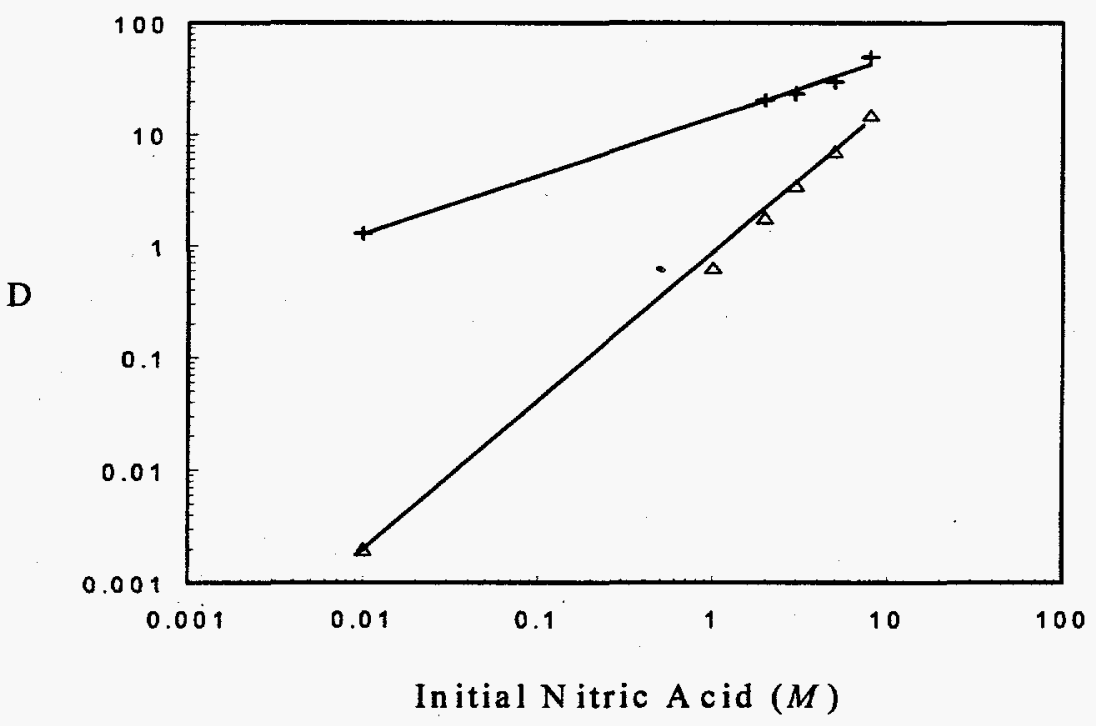

Figure 3. Dependence of distribution coefficients on initial nitric acid concentration for $0.001 M \mathrm{~Pb}(+)$ and $0.001 M \mathrm{Sr}(\Delta)$. Organic phase: $0.15 M \mathrm{DtBuCH} 18 \mathrm{C} 6$ and $1.2 M$ n-tributyl phosphate in Isopar $L^{\circledR}$.

\section{Stripping Behavior of Strontium and Lead}

The stripping behavior of $\mathrm{Sr}$ and $\mathrm{Pb}$ have been evaluated to determine effective methods for removing the extracted species from the loaded organic phase. This study utilized a simulated SBW and was performed by contacting the SREX solvent three times with equal volumes of the simulated SBW solution. The metal-loaded organic was then divided into three equal fractions for separate stripping procedures. The organic fractions were then contacted sequentially with four equal volumes of $0.01 \mathrm{M}$ nitric acid, $1 \mathrm{M}$ nitric acid, or $0.1 \mathrm{M}$ ammonium citrate. Tables 3 and 4 display the results of the study. 
The numbers shown are the amount of the metals in the aqueous phase, expressed as percent of the total quantity of the metal which was initially present in the organic phase after the extraction procedure, for each strip contact.

The case where $0.01 M$ nitric acid was used as the stripping reagent exhibits excellent stripping of $\mathrm{Sr}$ but inadequate stripping for $\mathrm{Pb}$. The low results for $\mathrm{Pb}$ can be predicted from the acid dependent plot for $\mathrm{Pb}$ in Figure 3. This curve shows that when the aqueous phase contains $0.01 \mathrm{M}$ nitric acid, the distribution coefficient for $\mathrm{Pb}$ remains above 0.5 . This suggests that $0.01 M$ nitric acid will not strip $\mathrm{Pb}$ from the loaded solvent efficiently. Tables 3 and 4 indicate that $1 M$ nitric acid is not effective for stripping either $\mathrm{Sr}$ or $\mathrm{Pb}$ from the loaded SREX solvent. This result is also expected based upon the extraction curves discussed previously.

The appearance of a cloudy precipitate in the aqueous phase, when dilute nitric acid was employed as a stripping reagent, was observed frequently during this investigation. This precipitate was determined to be composed primarily of insoluble lead complexes. This observation, and the inadequate stripping behavior discussed above, indicates that another stripping reagent must be identified for the stripping of $\mathrm{Pb}$. Ammonium citrate has been reported to be effective for removing $\mathrm{Pb}$ from extraction chromatographic resins based upon the $\mathrm{DtBuCH} 18 \mathrm{C} 6$ extractant. $^{6}$ This reagent may be decomposed under high thermal conditions and, therefore, may result in only slight increases in total mass in the resulting final waste form. Therefore, $0.1 \mathrm{M}$ ammonium citrate has been investigated as an alternative stripping reagent. Tables 3 and 4 display the data obtained from this study. Highly effective stripping of both $\mathrm{Sr}$ and $\mathrm{Pb}$ were obtained with this reagent. The $\mathrm{Sr}$ fraction was stripped quantitatively in the first two contacts. The $\mathrm{Pb}$ fraction was distributed among the four contacts with $86 \%$ of the fraction being stripped in the third contact. It should be noted that no precipitate was observed in the aqueous phases during this experiment. The elimination of the insoluble precipitates and the efficient removal of $\mathrm{Pb}$ from the organic phase indicates that ammonium citrate may be an effective reagent for use in the SREX process. These distribution coefficients were measured in pure $\mathrm{Pb}$ and $\mathrm{Sr}$ solutions which contained no additional interferences. Competing extractable ions may alter the selectivity and measured distribution coefficients.

Table 3. Amount of $\mathrm{Sr}$ present in aqueous phase as percent of total.

\begin{tabular}{lccccc}
\hline Stripping Reagent & Contact 1 & Contact 2 & Contact 3 & Contact 4 & Total \\
\hline $0.01 M$ nitric acid & 59.6 & 36.7 & 0.20 & 0.08 & 96.6 \\
$1 M$ nitric acid & 31.3 & 30.5 & 16.6 & 7.90 & 86.3 \\
$0.1 M$ ammonium citrate & 55.5 & 47.4 & 0.29 & 0.05 & 103 \\
\hline
\end{tabular}

Table 4. Amount of $\mathrm{Pb}$ present in aqueous phase as percent of total.

\begin{tabular}{lccccc}
\hline Stripping Reagent & Contact 1 & Contact 2 & Contact 3 & Contact 4 & Total \\
\hline $0.01 M$ nitric acid & 0.88 & 3.78 & 30.3 & 40.4 & 75.4 \\
$1 M$ nitric acid & 1.15 & 0.89 & 0.67 & 1.06 & 3.77 \\
$0.1 M$ ammonium citrate & 1.18 & 7.71 & 86.2 & 2.18 & 97.3 \\
\hline
\end{tabular}




\section{Batch Contact Solvent Extraction Flowsheets}

The data from the extraction and stripping studies have been used to propose an experimental batch contact flowsheet for demonstration of the simultaneous extraction of $\mathrm{Sr}$ and $\mathrm{Pb}$ from $\mathrm{SBW}$. The organic phase, consisting of $0.15 \mathrm{MDtBuCH} 18 \mathrm{C} 6$ in $1.2 \mathrm{MTBP}$ in Isopar $\mathrm{L}$, was contacted four times in succession with simulated SBW. The organic phase was separated from the aqueous phase in each contact and transferred to the next contact.

Four contacts of $0.05 \mathrm{M}$ nitric acid were employed following the extraction contacts as a method to remove nitric acid from the organic phase. A $0.05 \mathrm{M}$ nitric acid solution was selected in order to allow efficient acid scrubbing and strontium stripping, while avoiding the $\mathrm{Pb}$ precipitate which occurs with $0.01 \mathrm{M}$ nitric acid. Finally, four contacts of $0.1 \mathrm{M}$ ammonium citrate were employed to accomplish the metal stripping procedure. The results of the experimental flowsheet are presented in Table 5.

The measured distribution coefficients for $\mathrm{Sr}$ and $\mathrm{Pb}$ in the extraction contacts of the flowsheet reflected the expected range of values for $\mathrm{Sr}$. The $\mathrm{Pb}$ distribution coefficients were found to be sufficiently high to remove the $\mathrm{Pb}$ in quantitative amounts in all four extraction contacts. The subsequent contacts with $0.05 \mathrm{M}$ nitric acid efficiently stripped $\mathrm{Sr}$ from the loaded organic. These contacts did not, however, strip $\mathrm{Pb}$ from the organic phase. The $\mathrm{Pb}$ fraction remained primarily in the organic phase until the final strip contacts with $0.1 \mathrm{M}$ ammonium citrate. The largest portion of the $\mathrm{Pb}$ fraction was stripped from the organic phase on the first contact with ammonium citrate. This is due to the fact that most of the nitric acid which resided in the organic phase following the extraction contacts, was removed by the $0.05 \mathrm{M}$ nitric acid contacts. Based on these results, the countercurrent flowsheet shown in Figure 2 was developed and tested in the $5.5-\mathrm{cm}$ Centrifugal Contactor Mockup.

Table 5. Distribution coefficients for batch contact flowsheet.

\begin{tabular}{llll}
\hline Contact & Aqueous Phase & $\mathrm{Sr}$ & $\mathrm{Pb}$ \\
\hline 1 & SBW simulant & 4.2 & 587 \\
2 & SBW simulant & 3.9 & 113 \\
3 & SBW simulant & 3.8 & 89 \\
4 & SBW simulant & 4.0 & 75 \\
5 & $0.05 M$ nitric acid & 0.6 & 74 \\
6 & $0.05 M$ nitric acid & 0.12 & 40 \\
7 & $0.05 M$ nitric acid & $<0.01$ & 23 \\
8 & $0.05 M$ nitric acid & $<0.01$ & 3.4 \\
9 & $0.1 M$ ammonium citrate & $<0.01$ & 0.32 \\
10 & $0.1 M$ ammonium citrate & $<0.01$ & $<0.1$ \\
11 & $0.1 M$ ammonium citrate & $<0.01$ & $<0.1$ \\
12 & $0.1 M$ ammonium citrate & $<0.01$ & $<0.1$ \\
\hline
\end{tabular}




\section{SREX Flowsheet Testing}

\section{Contactor Operation}

Actual solution flowrates were calculated from feed tank depletion rates and are compared to the desired flowrates in Table 6. Due to the use of a small amount of aqueous feed in the 55 gallon feed vessel, a tank depletion flowrate was not determined for the aqueous feed. The SREX solvent was recycled during testing so a tank depletion rate could not be determined. However, the organic feed rotameter was calibrated with the SREX solvent prior to testing and a flowrate of $0.32 \mathrm{~L} / \mathrm{min}$ was obtained for the rotameter setting at which the SREX flowsheet testing was performed.

The 5.0 and 20.0 micron filters on the feed lines accumulated solids, causing partial plugging during operation. Also, a gel-like precipitate, consistent with the precipitate present in the SBW feed makeup vessel, was observed in stages 3 and 4 of the extraction section after shutdown. The precipitate was analyzed as primarily $\mathrm{Na}, \mathrm{Ca}, \mathrm{Al}, \mathrm{Sr}$, and $\mathrm{P}$. $\mathrm{Na}, \mathrm{Ca}$, and $\mathrm{Al}$ is also the major composition of the precipitate in the feed makeup vessel. Therefore, it is believed that obtaining the SBW feed from the bottom of the makeup vessel resulted in the carryover and/or formation of this precipitate in the feed for the flowsheet test. This precipitate is not representative of actual SBW solution and, therefore, is not expected to be present if actual SBW were being used. Flooding was not observed during testing.

Table 6. Flowrates and O/A ratios for SREX flowsheet testing.

\begin{tabular}{lcccccc}
\hline & & \multicolumn{2}{c}{ Flowrate (L/min) } & \multicolumn{2}{c}{ O/A Ratio } & Total Flow \\
Section & Phase & Desired & Actual & Desired & Actual & (L/min) \\
\hline All & Org. & 0.32 & nd & -- & -- & -- \\
Extraction & Aq. & 0.32 & nd & 1.0 & nd & 0.64 \\
Strip \#1 & Aq. & 0.60 & 0.66 & 0.53 & 0.48 & 0.98 \\
Strip \#2 & Aq. & 0.32 & 0.31 & 1.0 & 1.0 & 0.63 \\
$\begin{array}{l}\text { Nitric Acid } \\
\text { Equilibration }\end{array}$ & Aq. & 0.16 & 0.15 & 2.0 & 2.1 & 0.47 \\
\hline
\end{tabular}

\section{Concentrations at Shutdown}

The concentrations of $\mathrm{Sr}, \mathrm{Al}, \mathrm{Ca}, \mathrm{H}^{+}, \mathrm{Hg}, \mathrm{Na}, \mathrm{Pb}$, and $\mathrm{Zr}$ in each stream immediately prior to shutdown are given in Figure 4. Material balances for $\mathrm{Sr}, \mathrm{Al}, \mathrm{Ca}, \mathrm{H}^{+}, \mathrm{Hg}, \mathrm{Na}, \mathrm{Pb}$, and $\mathrm{Zr}$ are given in Table 7. The values in Table 7 were normalized to obtain an overall material balance of $100 \%$. Distribution coefficients were calculated for $\mathrm{Sr}$ and $\mathrm{Pb}$ for each of the 16 stages. The resulting distribution coefficients are given in Table 8. A discussion of the behavior of each component follows. 


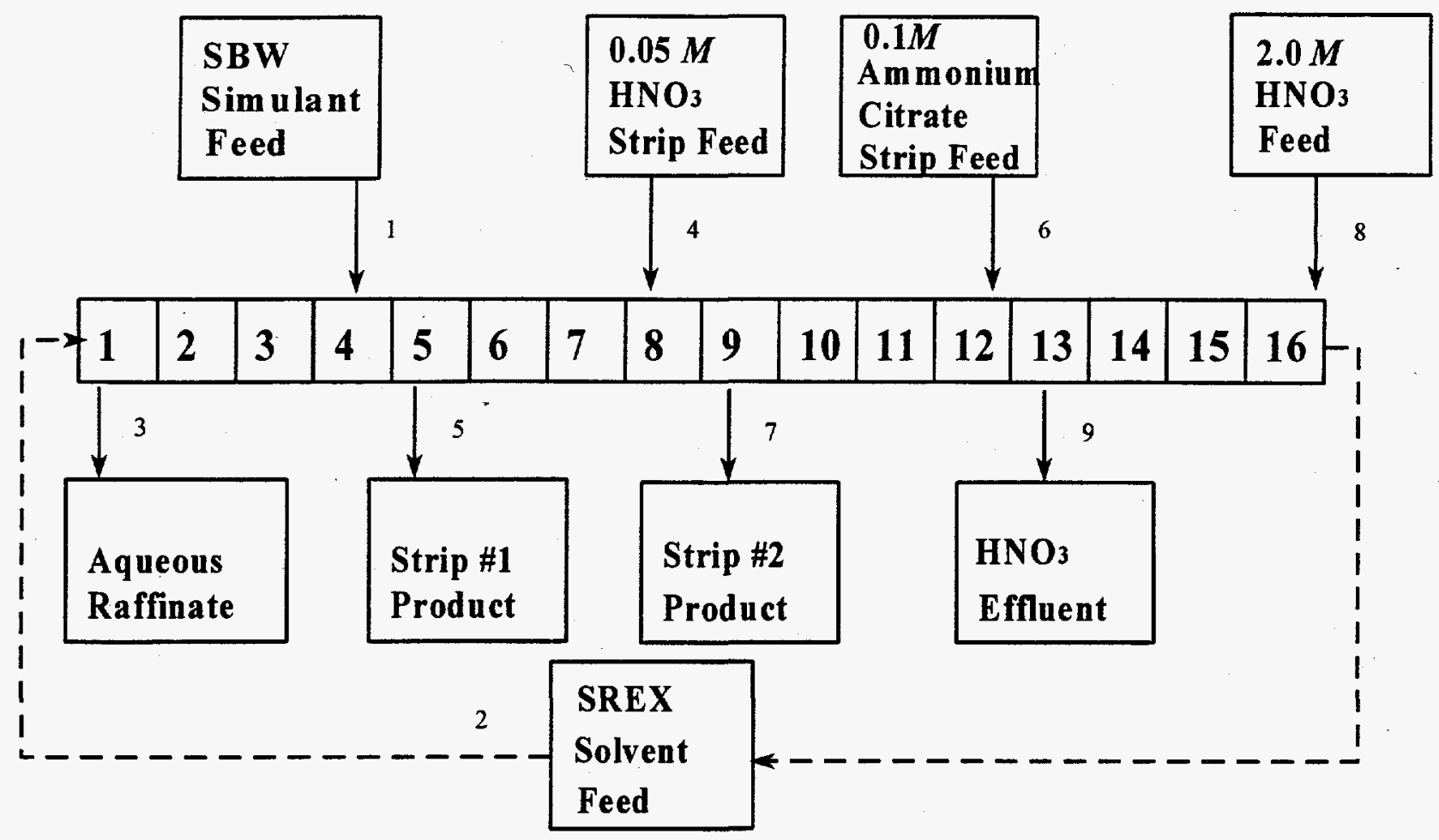

\begin{tabular}{|c|c|c|c|c|c|c|c|c|c|}
\hline Component & $\begin{array}{l}\text { SBW } \\
\text { Feed } \\
1\end{array}$ & $\begin{array}{l}\text { SREX Solvent } \\
\text { Feed } \\
2\end{array}$ & $\begin{array}{l}\text { LAW } \\
\text { Raff. } \\
3\end{array}$ & $\begin{array}{l}\text { Strip \#1 } \\
\text { Feed } \\
4\end{array}$ & $\begin{array}{l}\text { Strip \#1 } \\
\text { Product } \\
5\end{array}$ & $\begin{array}{l}\text { Strip \#2 } \\
\text { Feed } \\
6\end{array}$ & $\begin{array}{l}\text { Strip \#2 } \\
\text { Product } \\
7\end{array}$ & $\begin{array}{l}\mathrm{HNO}_{3} \\
\text { Feed } \\
8\end{array}$ & $\begin{array}{l}\mathrm{HNO}_{3} \\
\text { Effluent } \\
9\end{array}$ \\
\hline $\mathrm{H}^{+}(M)$ & 1.35 & -- & 1.00 & 0.05 & 0.55 & -- & --- & 2.0 & 0.79 \\
\hline $\mathrm{NH}_{4}(M)$ & -- & -- & - & -- & - & 0.1 & 0.1 & -- & -- \\
\hline $\operatorname{Sr}(M)$ & $6.80 \mathrm{E}-03$ & $7.42 \mathrm{E}-07$ & $1.27 \mathrm{E}-04$ & $\cdots$ & $2.85 \mathrm{E}-03$ & $\cdots$ & $1.48 \mathrm{E}-07$ & $\cdots$ & $<4.57 \mathrm{E}-08$ \\
\hline $\mathrm{Pb}(M)$ & $9.27 \mathrm{E}-04$ & $<3.84 \mathrm{E}-06$ & $<7.67 \mathrm{E}-07$ & -- & $8.00 \mathrm{E}-06$ & --- & 8.58E-04 & -- & $<7.67 \mathrm{E}-07$ \\
\hline $\mathrm{Al}(M)$ & 0.56 & -- & 0.57 & $\cdots$ & 0.023 & -- & $1.99 \mathrm{E}-05$ & $\cdots$ & $3.00 \mathrm{E}-05$ \\
\hline $\mathrm{Ca}(M)$ & $9.83 \mathrm{E}-02$ & $\cdots$ & $4.81 \mathrm{E}-02$ & -- & $2.39 \mathrm{E}-03$ & --- & $3.60 \mathrm{E}-05$ & $\cdots$ & $3.79 \mathrm{E}-05$ \\
\hline $\mathrm{Hg}(M)$ & $1.93 \mathrm{E}-03$ & -- & $3.01 \mathrm{E}-05$ & --- & $4.54 \mathrm{E}-05$ & $\cdots$ & $4.86 \mathrm{E}-04$ & -- & $7.93 \mathrm{E}-06$ \\
\hline $\mathrm{Na}(M)$ & 1.32 & -- & 0.95 & $\cdots$ & $5.48 \mathrm{E}-02$ & $\cdots$ & $1.69 \mathrm{E}-04$ & -- & $1.10 \mathrm{E}-04$ \\
\hline $\operatorname{Zr}(M)$ & $8.77 \mathrm{E}-03$ & -- & $1.41 \mathrm{E}-03$ & -- & $4.50 \mathrm{E}-03$ & $\ldots$ & $7.47 \mathrm{E}-05$ & $\cdots$ & $3.86 \mathrm{E}-06$ \\
\hline Flowrate (L/min) & 0.32 & 0.32 & 0.32 & 0.60 & 0.60 & 0.32 & 0.32 & 0.16 & 0.16 \\
\hline
\end{tabular}

Figure 4. SREX flowsheet test steady state concentrations. 
Table 7. Percentage of component in each of the effluent streams for SREX flowsheet testing.

\begin{tabular}{|c|c|c|c|c|c|c|c|}
\hline Stream & $\mathrm{Sr}$ & $\mathrm{Pb}$ & $\mathrm{Al}$ & $\mathrm{Ca}$ & $\mathrm{Hg}$ & $\mathrm{Na}$ & $\mathrm{Zr}$ \\
\hline Aqueous Raffinate & $\begin{array}{c}1.9 \% \\
(2.1 \%)^{\mathrm{a}}\end{array}$ & $\begin{array}{c}0.083 \% \\
(0.090 \%)\end{array}$ & $\begin{array}{l}101.9 \% \\
(92.4 \%)\end{array}$ & $\begin{array}{l}49.0 \% \\
(90.6 \%)\end{array}$ & $\begin{array}{l}1.6 \% \\
(5.0 \%)\end{array}$ & $\begin{array}{c}71.7 \% \\
(89.3 \%)\end{array}$ & $\begin{array}{c}16.1 \% \\
37.4 \%\end{array}$ \\
\hline Strip \#1 Product & $\begin{array}{l}86.3 \% \\
(97.9 \%)\end{array}$ & $\begin{array}{r}1.8 \% \\
(1.9 \%)\end{array}$ & $\begin{array}{c}8.4 \% \\
(7.6 \%)\end{array}$ & $\begin{array}{c}5.0 \% \\
(9.3 \%)\end{array}$ & $\begin{array}{c}4.8 \% \\
(15.7 \%)\end{array}$ & $\begin{array}{l}8.5 \% \\
(10.6 \%)\end{array}$ & $\begin{array}{l}26.7 \% \\
(62.1 \%)\end{array}$ \\
\hline Strip \#2 Product & $\begin{array}{l}0.002 \% \\
(0.002 \%)\end{array}$ & $\begin{array}{l}89.6 \% \\
(97.9 \%)\end{array}$ & $\begin{array}{l}0.003 \% \\
(0.003 \%)\end{array}$ & $\begin{array}{l}0.04 \% \\
(0.07 \%)\end{array}$ & $\begin{array}{l}24.3 \% \\
(78.7 \%)\end{array}$ & $\begin{array}{l}0.012 \% \\
(0.015 \%)\end{array}$ & $\begin{array}{l}0.21 \% \\
(0.48 \%)\end{array}$ \\
\hline $\begin{array}{l}\text { Nitric Acid } \\
\text { Effluent }\end{array}$ & $\begin{array}{l}<3 \mathrm{E}-4 \% \\
(<4 \mathrm{E}-4 \%)\end{array}$ & $\begin{array}{l}<0.04 \% \\
(<0.04 \%)\end{array}$ & $\begin{array}{l}0.002 \% \\
(0.002 \%)\end{array}$ & $\begin{array}{l}0.02 \% \\
(0.03 \%)\end{array}$ & $\begin{array}{l}0.2 \% \\
(0.6 \%)\end{array}$ & $\begin{array}{l}0.004 \% \\
(0.005 \%)\end{array}$ & $\begin{array}{l}0.02 \% \\
(0.05 \%)\end{array}$ \\
\hline $\begin{array}{l}\text { Solvent } \\
\text { Effluent }\end{array}$ & $0.01 \%$ & $0.4 \%$ & $n^{c}{ }^{c}$ & nd & nd & nd & nd \\
\hline Mass Balance ${ }^{b}$ & $88.2 \%$ & $91.5 \%$ & $110.3 \%$ & $54.0 \%$ & $30.9 \%$ & $80.3 \%$ & $43.0 \%$ \\
\hline
\end{tabular}

Table 8. $\mathrm{Sr}$ and $\mathrm{Pb}$ distribution coefficients for SREX flowsheet testing.

\begin{tabular}{ccll}
\hline Section & Stage & $\mathrm{D}_{\mathrm{S} \mathrm{r}}$ & $\mathrm{D}_{\mathrm{Pb}}$ \\
\hline \multirow{2}{*}{ Extraction } & 1 & & \\
& 2 & 2.5 & $>14$ \\
& 3 & 2.4 & $>8.3$ \\
& 4 & 3.1 & $>260$ \\
Strip \#1 & 5 & 2.0 & 45 \\
& 6 & 0.80 & 156 \\
& 7 & 0.33 & 3.3 \\
Strip \#2 & 8 & 0.093 & 4.8 \\
& 9 & 1.8 & 4.2 \\
& 10 & 3.9 & 0.075 \\
Nitric Acid Equilibration & 11 & 0.15 & $<0.55$ \\
& 13 & 0.22 & nd \\
& 14 & 1.8 & nd \\
& 15 & $>15$ & nd \\
& 16 & $>14$ & nd \\
& 13 & 17 & nd \\
& 15 & 15 & nd \\
\hline
\end{tabular}

a. Not determined. 
Strontium. The Sr concentration was reduced from $6.80 \mathrm{E}-03 \mathrm{M}$ in the feed to $1.27 \mathrm{E}-04 M$ in the raffinate. This corresponds to $97.9 \% \mathrm{Sr}$ removal with only four extraction stages. Distribution coefficients in the extraction section ranged from 2.0 to 3.1 , which is consistent with results from previous testing. ${ }^{5}$ Re-equilibration of the stage 2 aqueous and organic phases resulted in the $\mathrm{Sr}$ distribution increasing from 2.4 to 3.2 (33\% increase). Low stage efficiency was also observed in previous SREX flowsheet testing at the INEL and at ANL. The $0.05 \mathrm{M}$ nitric acid strip section was very effective in back-extracting the $\mathrm{Sr}$ from the SREX solvent. $99.97 \%$ of the $\mathrm{Sr}$ was stripped from the SREX solvent with the four strip stages.

Lead. Distribution coefficients for $\mathrm{Pb}$ in the extraction section ranged from $>8$ to $>261$. As a result, $99.9 \%$ of the $\mathrm{Pb}$ was extracted into the SREX solvent. The $0.05 \mathrm{M}$ nitric acid strip section ( $\mathrm{Sr}$ strip) back-extracted $1.9 \%$ of the $\mathrm{Pb}$ from the solvent. Distribution coefficients in this section ranged from 3.3 to 156 . The four stages of ammonium citrate strip effectively removed all but $0.4 \%$ of the $\mathrm{Pb}$ from the SREX solvent.

Aluminum, calcium, mercury, sodium, and zirconium. As expected, $\mathrm{Hg}$ and $\mathrm{Zr}$ were extracted by the SREX solvent ( $95 \%$ of the $\mathrm{Hg}$ and $63 \%$ of the $\mathrm{Zr}$ ). In addition, $7.6 \%$ of the $\mathrm{Al}, 9.4 \%$ of the $\mathrm{Ca}$ and $10.6 \%$ of the Na were extracted. These species were effectively stripped from the SREX solvent in the two strip sections. It should be noted that the overall material balances were very poor for each of . these species. It is expected that the poor material balances are a result of the precipitates $(\mathrm{Na}, \mathrm{Ca}, \mathrm{Al})$ present in the feed solution and in the extraction section.

Acid. Distribution coefficients for $\mathrm{H}^{+}$ranged from 0.66 to 0.75 in the extraction section, 0.13 to 0.41 in the nitric acid strip section, 0.023 to 0.037 in the ammonium citrate strip section, and 0.26 to 0.31 in the nitric acid equilibration section. These distribution coefficients are in good agreement with $\mathrm{H}^{+}$data from previous SREX testing. ${ }^{5}$ The $0.05 \mathrm{M}$ nitric acid strip back-extracted $99.3 \%$ of the $\mathrm{H}^{+}$from the SREX solvent. As a result, the $\mathrm{H}^{+}$concentration in the ammonium citrate strip section remained low enough to effectively strip the $\mathrm{Pb}$ from the SREX solvent.

Potassium. Samples from this test were not analyzed for potassium. The SREX solvent will typically extract potassium. Previous testing in the $5.5-\mathrm{cm}$ Centrifugal Contactor mockup resulted in $53 \%$ of the potassium extracted with eight extraction stages $\left(D_{K}=0.6\right)$. The extracted potassium was effectively stripped from the SREX solvent with dilute $\mathrm{HNO}_{3}$. 


\section{CONCLUSIONS AND RECOMMENDATIONS}

\section{Conclusions}

Lead and strontium were extracted and selectively stripped from the SBW simulant. Removal efficiencies of $97.9 \%$ and $99.91 \%$ were obtained for $\mathrm{Sr}$ and $\mathrm{Pb}$, respectively (four extraction stages). It should be noted that a Sr removal efficiency of $99.98 \%$ was previously demonstrated with eight extraction stages. ${ }^{5} 99.998 \%$ of the extracted $\mathrm{Sr}$ and $1.9 \%$ of extracted $\mathrm{Pb}$ exited with the $0.05 \mathrm{M}$ nitric acid strip product. $0.002 \%$ of the extracted $\mathrm{Sr}$ and $97.9 \%$ of the extracted $\mathrm{Pb}$ exited with the $0.1 M$ ammonium citrate strip product.

Mercury and zirconium were extracted $(95 \%$ of the $\mathrm{Hg}$ and $63 \%$ of the $\mathrm{Zr}$ ) by the SREX solvent and successfully stripped in the ammonium citrate and nitric acid strip sections, respectively.

Flooding and/or third phase formation were not observed during testing. A gel-like precipitate, consistent with the precipitate present in the SBW feed makeup vessel, was observed in stages 3 and 4 of the extraction section after shutdown. The precipitate was analyzed as primarily $\mathrm{Na}, \mathrm{Ca}, \mathrm{Al}, \mathrm{Sr}$, and $\mathrm{P}$. $\mathrm{Na}, \mathrm{Ca}$, and $\mathrm{Al}$ is also the major composition of the precipitate in the feed makeup vessel. Therefore, it is believed that obtaining the SBW feed from the bottom of the makeup vessel resulted in the carryover and/or formation of this precipitate in the feed for the flowsheet test. This precipitate is not representative of actual SBW solution and, therefore, is not expected to be present if actual SBW were being treated.

\section{Recommendations}

This flowsheet should be used as a basis for performing SREX flowsheet testing with actual tank waste in the $2.0-\mathrm{cm}$ centrifugal contactors located in the Remote Analytical Laboratory hot cell. 


\section{REFERENCES}

1. A. L Olson, W. W. Schulz, L. A. Burchfield, C. D. Carlson, J. L. Swanson, and M. C. Thompson, Evaluation and Selection of Aqueous Based Technology for Partitioning Radionuclides from ICPP Calcine, WINCO-1071, February 1993.

2. E. P. Horwitz, D. G. Kalina, H. Diamond, and G. F. Vandegrift, Solvent Extr. \& Ion Exch., $\underline{3}(1 \& 2)$, $75,1985$.

3. E. P. Horwitz, M. L. Dietz, and D. E. Fisher, "SREX: A New Process for the Extraction and Recovery of Strontium from Acidic Nuclear Waste Streams," Sol. Extr. \& Ion Exch., 9(1),1-25, 1991.

4. D. J. Wood and J. D. Law, "Evaluation of the SREX Solvent Extraction Process for the Removal of ${ }^{90} \mathrm{Sr}$ and Hazardous Metals from Acidic Nuclear Waste Solutions Containing High Concentrations of Interfering Alkali Metal Ions," Separation Science and Technology, in press, January 1997.

5. J. D. Law, D. J. Wood, and R. S. Herbst, SREX Flowsheet Development for the Separation of Strontium from ICPP Sodium-Bearing Waste Using Centrifugal Contactors, INEL-95/0314, September 1995.

6. E. P. Horwitz, et. al., Anal. Chim. Acta, 292, (1994), 263-273 

APPENDIX A

\section{EXPERIMENTAL DATA}


Table A-1. Stage samples after shutdown

\begin{tabular}{lllllll}
\hline Stage & $\mathrm{H}^{+}$ & $\mathrm{H}^{+}$ & $\mathrm{Sr}$ & $\mathrm{Sr}$ & $\mathrm{Pb}$ & $\begin{array}{l}\text { Pb } \\
\text { Org. }(M)\end{array}$ \\
\hline 1 & Aq. $(M)$ & Org. $(M)$ & Aq. $(M)$ & Org. $(M)$ & Aq. $(M)$ & $1.11 \mathrm{E}-05$ \\
2 & 1.003 & 0.755 & $1.31 \mathrm{E}-04$ & $3.23 \mathrm{E}-04$ & $<7.67 \mathrm{E}-07$ & $6.37 \mathrm{E}-06$ \\
3 & 1.177 & 0.778 & $4.36 \mathrm{E}-04$ & $1.06 \mathrm{E}-03$ & $<7.67 \mathrm{E}-07$ & $2.00 \mathrm{E}-04$ \\
4 & 1.247 & 0.846 & $1.21 \mathrm{E}-03$ & $3.70 \mathrm{E}-03$ & $<7.67 \mathrm{E}-07$ & $6.28 \mathrm{E}-04$ \\
5 & 1.293 & 0.844 & $3.12 \mathrm{E}-03$ & $6.14 \mathrm{E}-03$ & $1.39 \mathrm{E}-05$ & $1.17 \mathrm{E}-03$ \\
6 & 0.549 & 0.223 & $2.92 \mathrm{E}-03$ & $2.34 \mathrm{E}-03$ & $7.53 \mathrm{E}-06$ & $1.53 \mathrm{E}-03$ \\
7 & 0.166 & 0.043 & $1.09 \mathrm{E}-03$ & $3.61 \mathrm{E}-04$ & $4.61 \mathrm{E}-04$ & $1.44 \mathrm{E}-03$ \\
8 & 0.048 & 0.0066 & $1.90 \mathrm{E}-05$ & $1.77 \mathrm{E}-06$ & $3.00 \mathrm{E}-04$ & $9.30 \mathrm{E}-04$ \\
9 & 0.046 & 0.006 & $3.77 \mathrm{E}-07$ & $6.85 \mathrm{E}-07$ & $2.23 \mathrm{E}-04$ & $<.66 \mathrm{E}-05$ \\
10 & 0.128 & 0.003 & $2.05 \mathrm{E}-07$ & $7.99 \mathrm{E}-07$ & $8.94 \mathrm{E}-04$ & $<3.84 \mathrm{E}-06$ \\
11 & 0.139 & 0.004 & $5.26 \mathrm{E}-06$ & $7.99 \mathrm{E}-07$ & $6.92 \mathrm{E}-06$ & $<3.84 \mathrm{E}-06$ \\
12 & 0.136 & 0.005 & $5.51 \mathrm{E}-06$ & $1.20 \mathrm{E}-06$ & $<7.67 \mathrm{E}-07$ & $<3.84 \mathrm{E}-06$ \\
13 & 0.139 & 0.005 & $4.11 \mathrm{E}-07$ & $7.42 \mathrm{E}-07$ & $<7.67 \mathrm{E}-07$ & $<3.84 \mathrm{E}-06$ \\
14 & 0.788 & 0.208 & $<4.57 \mathrm{E}-08$ & $6.85 \mathrm{E}-07$ & $<7.67 \mathrm{E}-07$ & $<3.84 \mathrm{E}-06$ \\
15 & 1.22 & 0.343 & $<4.57 \mathrm{E}-08$ & $6.28 \mathrm{E}-07$ & $<7.67 \mathrm{E}-07$ & $<3.84 \mathrm{E}-06$ \\
16 & 1.528 & 0.474 & $4.57 \mathrm{E}-08$ & $7.99 \mathrm{E}-07$ & $<7.67 \mathrm{E}-07$ & $<3.84 \mathrm{E}-06$ \\
\hline
\end{tabular}

Table A-2. Steady State Samples

\begin{tabular}{|c|c|c|c|c|c|c|c|c|c|c|c|}
\hline a & $\begin{array}{c}\mathrm{H}^{+} \\
\mathrm{Aq} .(M)\end{array}$ & $\begin{array}{c}\mathrm{H}^{+} \\
\text {Org. }(M)\end{array}$ & $\begin{array}{c}\mathrm{Sr} \\
\text { Aq. }(M)\end{array}$ & $\begin{array}{c}\mathrm{Sr} \\
\text { Org. }(M)\end{array}$ & $\begin{array}{c}\mathrm{Pb} \\
\text { Aq. }(M)\end{array}$ & $\begin{array}{c}\mathrm{Pb} \\
\text { Org.(M) }\end{array}$ & $\begin{array}{c}\mathrm{Al} \\
\mathrm{Aq}(\mathrm{ppm})\end{array}$ & $\begin{array}{c}\mathrm{Ca} \\
\mathrm{Aq}(\mathrm{ppm})\end{array}$ & $\begin{array}{c}\mathrm{Hg} \\
\mathrm{Aq}(\mathrm{ppm})\end{array}$ & $\begin{array}{c}\mathrm{Na} \\
\mathrm{Aq}(\mathrm{ppm})\end{array}$ & $\begin{array}{c}\mathrm{Zr} \\
\mathrm{Aq}(\mathrm{ppm})\end{array}$ \\
\hline Raffinate & 1.022 & nd & $1.27 \mathrm{E}-04$ & nd & $<7.67 \mathrm{E}-07$ & nd & 15280 & 1929.2 & 6.03 & 21800 & 128.44 \\
\hline Strip \#1 prod. & 0.479 & nd & $2.85 E-03$ & nd & 8.00E-06 & nd & 612.8 & 95.76 & 9.1 & 1260 & 103.5 \\
\hline Strip \#2 prod & 0.139 & nd & $1.48 \mathrm{E}-07$ & nd & 8.58E-04 & nd & 0.537 & 1.444 & 97.4 & 3.88 & 1.717 \\
\hline $\mathrm{HNO}_{3}$ effluent & 0.786 & nd & $<4.57 \mathrm{E}-08$ & nd & $<7.67 \mathrm{E}-07$ & nd & 0.81 & 1.521 & 1.59 & 2.53 & 0.352 \\
\hline Solvent effluent & nd & nd & nd & $7.42 \mathrm{E}-07$ & nd & $<3.84 \mathrm{E}-06$ & nd & nd & nd & nd & nd \\
\hline Feed & 1.346 & nd & $6.80 \mathrm{E}-03$ & nd & 9.27E-04 & nd & 15000 & 3940.8 & 388 & 30400 & 799.4 \\
\hline
\end{tabular}

